\title{
Economic Evaluation of Some Botanical Oils for the Control of Onion Thrips (Thrips tabaci Lind.; Thysanoptera: Thripidae) and Onion Yield
}

\section{Wessal YHA ${ }^{1}$, Hassan $0^{2}{ }^{2}$ Ammar MS Abdalla ${ }^{3 *}$}

${ }^{1}$ Faculty of Agricultural Sciences, University of Dongla, Dongla, Sudan

${ }^{2}$ Agricultural Research Corporation (ARC), Wad Medani, Sudan

${ }^{3}$ Department of Crop Protection, Faculty of Agricultural Sciences (FAS), University of Dongola, Dongola, Sudan

*Corresponding Author: Ammar MS Abdalla, Department of Crop Protection, Faculty of Agricultural Sciences (FAS), University of

Dongola, Dongola, Sudan.

Received: July 04, 2019; Published: July 23, 2019

DOI: 10.31080 /ASPS.2019.03.0351

\section{Abstract}

Two field experiments were carried out in two successive seasons (2006/2007-2007/2008) in two sites; the first site at Arbaji Farm, on the Blue Nile Bank, Gezira State and the other in Nidiana block, Massalamia Group, at the Gezira Scheme. The experiments aimed at studying the efficacy of some botanical oils including sesame, cotton, groundnut, and sunflower oil on thrips, Thrips tabaci (Lind.) population and onion yield compared to the standard commercial insecticide Karate 5\% EC (lambda-cyhalothrin).Economic evaluation was carried as well.. The yield data showed highly significant differences between treatments in the two testing seasons with exception to site two in 2007/08 season. However, a remarkable yield increase was recorded from Karate treatment throughout the course of the study and in both seasons. Generally, the control treatment scored the lowest yield throughout the test period which explains the importance of the pest damage if left unchecked.

Statistical analysis showed that Karate, groundnut oil 5\% and sesame oil 5\% were very effective for the control of onion thrips. Some treatments had high net benefit but at high cost. For this reason, dominance and marginal analysis were used for ranking the most cost effective treatments. The marginal rate of return (MRR) was calculated to show the rate of benefit or return of onion production. According to analysis the MRR ranged between 4 - 3.49.This indicated that an increase in treatments cost will be covered by the increase in yield as a result of the application of these treatments. This recommended level was considered the most highly profitable and economically feasible for onion production. For Karate treatment, each one Sudanese pound. 1SDG, invested gave 3.49 SDG extra net return compared with cotton oil $2.5 \%$ treatment. In addition, for groundnut oil 5\% treatment, each 1SDG invested gave 0.3 SDG extra net return compared with Karate treatment. For sesame oil 5\% treatment each 1 SDG invested gave 0.04 SDG extra net return compared with groundnut oil $5 \%$ treatment.

Keywords: Onion Thrips; Botanical Oils; Onion Yield

\section{Introduction}

Onion (Allium cepa L.) is one of the most important vegetable crops worldwide, used by all people for its nutritional and medicinal values. The plant originated in southeast Asia, and introduced in Sudan long time ago [1]. The main producing areas for onion in Sudan are: Kassala in the Eastern State Dongola and Shendi in the Northern State, Zalengi in Darfur State, Gezira and Rahad Schemes [2]. Onion is the main vegetable crop in the Gezira State, which represents about $42 \%$ of the total vegetables area grown in the Gezira Scheme and $28 \%$ of the whole area grown in the Scheme. Sudanese farmers are well skilled in onion production specially in Kassala, Gezira and River Nile State [1]. In the Sudan, the area cropped with onion was estimated to be 12,000 ha and the total production was 80,000 tons [3]. Omara [4], estimated the area annually cropped with Onion to be around 20,000 ha. capsule [5]. Among various pests which attack the crop, onion thrips caused the major losses to the crop. The other important insect pest is the lesser army worm, Spodoptera exigua $\mathrm{Hb}$, which feeds on onion leaves leading to leaf shedding and the third one is the cutworm, Agrotis ipsilon $\mathrm{Hb}$ [6].

This recent study may help to launch the development of a sound integrated pest management approach through the use of some edible oils in comparison to the conventional standard insecticide application for the control of onion thrips and onion yield. The economic evaluation of these oils added a further dimension 
to the biological efficacy of the oils. However, these tested oils were refined ones for the sake of their availability to the vegetable grower from the local market. Crude oils could have been more potent as reported by Jacobson [7] for groundnut and cottonseed oils. However, the use of sesame oil to control whitefly on tomato in Sudan was recommended by Yassin., et al. [8]. Again, Elamin [9] reported that sesame oil (refined) at $2-3 \%$ as oil water emulsion + Agaral (or liquid soap) led to significant decrease in TYLCV and significant increase in yield. It should be mentioned that the type of oil, as reported by Cranshaw [10] can greatly affect its activity. This could possibly be explained in terms of botanical origin i.e. plant sp. as well as the treatment the oil receives. Accordingly, further experimentation with crude botanical oils for the control of thrips on onion could lead to more positive results.

\section{Materials and Method}

The study was carried out in two sites for two seasons (2006/2007 and 2007/2008), at the Gezira state; the first site at the Western Blue Nile Bank (Arbaji village) and the other in the Gezira Scheme, Massalamia Group, Nidiana block. In each season the experimental area was prepared according to the standard recommended land preparation procedures adopted by farmers for successful onion production [11]. The efficacy of some botanical oils; including cotton seed oil, sesame oil, sunflower oil and groundnut oil for the control of onion thrips in onion was tested in comparison to the standard commercial insecticide Karate 5\% EC (lambda -cyhalothrin)/ The oils were obtained from Wad Medani local market i.e. refined oils, for ease of being obtained by vegetable growers later on. Oils were diluted with water and applied as aqueous solutions mixed with few drops of liquid soap and Molass (as an anti UV light). The onion variety used was Saggai obtained from a known source at the vegetables central market, Wad Medani, Sudan. In both sites and during both seasons each experiment was arranged in a Randomized Complete Block design (RCBD) with three replications. The experimental fields in both sites consisted of 14 treatments. Botanical oils were evaluated at 3 different rates. The treatments and their dosage rates were as follow:

1. Sesame oil at the rate of $1.5 \%$ concentration (Ses. $1.5 \%$ )

2. Sesame oil at the rate of $2.5 \%$ concentration (Ses. $2.5 \%$ )

3. Sesame oil at the rate of $5 \%$ concentration (Ses.5.0\%)

4. Cotton seed oil at the rate of $1.5 \%$ concentration (Cott. 1.5\%)

5. Cotton seed oil at the rate of $2.5 \%$ concentration (Cott. $2.5 \%$ )

6. Cotton seed oil at the rate of $5 \%$ concentration (Cott. $5.0 \%$ )

7. Groundnut oil at the rate of $1.5 \%$ concentration (G/N. $1.5 \%$ )

8. Groundnut oil at the rate of $2.5 \%$ concentration $(\mathrm{G} / \mathrm{N} .2 .5 \%)$

9. Groundnut oil at the rate of $5 \%$ concentration (G/N. $5.0 \%$ )

10. Sunflower oil at the rate of $1.5 \%$ concentration (S/F. $1.5 \%)$
11. Sunflower oil at the rate of $2.5 \%$ concentration (S/F. $2.5 \%$ )

12. Sunflower oil at the rate of $5 \%$ concentration (S/F. 5.0\%)

13. Karate $5 \%$ EC (lambda-cyhalothrin) at the rate of $150 \mathrm{ml} /$ fed.(7.5\% g a.i/fed.)

14. Untreated Control (UTC)

The data presented in this study were based on the results collected from tow field experiments conducted in onion during 20062008 seasons.

Bulb weight was taken and recorded. Bulb yields were estimated from the central area in each subplot where three-square meters were randomly estimated in the subplot.

The data was subjected to the Analysis of Variance (ANOVA), and the values of the grand mean, standard error and coefficient of variation were calculated. Duncan's Multiple Range Test (DMRT) was used to separate means among treatment.

\section{Results and Discussion}

Assessment of onion yields

The bulb yield results are shown in Tables 1, 2 for the two seasons 2006/07 and 2007/08. The data presented in Table 1 revealed that Karate displayed an outstanding performance for the control of onion thrips. Besides, it gave a remarkable yield increase in the two testing sites during the course of the study.

\begin{tabular}{|l|c|c|}
\hline \multicolumn{1}{|c|}{ Treatments } & Site one & Site two \\
\hline 1. Ses.1.5\% & $(5.7)$ bcdefg & $(5.3) \mathrm{cdef}$ \\
\hline 2. Ses.2.5\% & $(6.5) \mathrm{bcdef}$ & $(7.1) \mathrm{bc}$ \\
\hline 3. Ses. 5\% & $(7.9) \mathrm{b}$ & $(8.8) \mathrm{ab}$ \\
\hline 4. Cott.1.5\% & $(4.4) \mathrm{efg}$ & $(3.7) \mathrm{f}$ \\
\hline 5. Cott.2.5\% & $(6.8) \mathrm{bcdef}$ & $(6.5) \mathrm{cde}$ \\
\hline 6. Cott. 5\% & $(7.4) \mathrm{bc}$ & $(7.2) \mathrm{bc}$ \\
\hline 7. G/N.1.5\% & $(6.6) \mathrm{bcde}$ & $(6.7) \mathrm{bcd}$ \\
\hline 8. G/N.2.5\% & $(6.7) \mathrm{bcde}$ & $(6.7) \mathrm{bcd}$ \\
\hline 9. G/N. 5\% & $(7.1) \mathrm{bcd}$ & $(7.1) \mathrm{bc}$ \\
\hline 10. S/F.1.5\% & $(4.1) \mathrm{fg}$ & $(4.9) \mathrm{def}$ \\
\hline 11. S/F.2.5\% & $(4.6) \mathrm{defg}$ & $(5.9) \mathrm{cdef}$ \\
\hline 12. S/F. 5\% & $(5.0) \mathrm{cdefg}$ & $(4.6) \mathrm{ef}$ \\
\hline 13. Karate 5\% EC & $(8.5) \mathrm{a}$ & $(9.0) \mathrm{a}$ \\
\hline 14. UTC & $(3.3) \mathrm{g}$ & $(3.7) \mathrm{f}$ \\
\hline SE \pm & 0.7 & 0.6 \\
\hline CV\% & 19.2 & 17.1 \\
\hline
\end{tabular}

Table 1: Mean onion bulb yield (T/Fed.). Season 2006/07. $\mathrm{T} /$ Fed. $=$ Ton $/$ Feddan 


\begin{tabular}{|l|c|c|}
\hline \multicolumn{1}{|c|}{ Treatments } & Site one & Site two \\
\hline 1. Ses.1.5\% & $(6.1) \mathrm{bc}$ & $(6.2) \mathrm{a}$ \\
\hline 2. Ses.2.5\% & $(6.8) \mathrm{bc}$ & $(7.2) \mathrm{a}$ \\
\hline 3. Ses. 5\% & $(8.3) \mathrm{b}$ & $(7.7) \mathrm{a}$ \\
\hline 4. Cott.1.5\% & $(6.1) \mathrm{bc}$ & $(7.5) \mathrm{a}$ \\
\hline 5. Cott.2.5\% & $(6.7) \mathrm{bc}$ & $(7.0) \mathrm{a}$ \\
\hline 6. Cott. 5\% & $(7.3) \mathrm{bc}$ & $(7.3) \mathrm{a}$ \\
\hline 7. G/N.1.5\% & $(6.0) \mathrm{bc}$ & $(8.4) \mathrm{a}$ \\
\hline 8. G/N.2.5\% & $(7.3) \mathrm{bc}$ & $(7.4) \mathrm{a}$ \\
\hline 9. G/N. 5\% & $(8.1) \mathrm{b}$ & $(7.5) \mathrm{a}$ \\
\hline 10. S/F.1.5\% & $(5.4) \mathrm{bc}$ & $(5.2) \mathrm{a}$ \\
\hline 11. S/F.2.5\% & $(7.7) \mathrm{b}$ & $(6.9) \mathrm{a}$ \\
\hline 12. S/F. 5\% & $(7.0) \mathrm{bc}$ & $(7.9) \mathrm{a}$ \\
\hline 13. Karate 5\% EC & $(7.5) \mathrm{bc}$ & $(7.5) \mathrm{a}$ \\
\hline 14. UTC & $(4.7) \mathrm{c}$ & $(6.0) \mathrm{a}$ \\
\hline SE \pm & 0.8 & 1.0 \\
\hline CV\% & 19.1 & 23.3 \\
\hline
\end{tabular}

Table 2: Mean onion bulb yield (T/ Fed.). Season 2007/08. $\mathrm{T} /$ Fed. $=$ Ton $/$ Feddan

Significant differences between treatments were observed during both seasons. Meanwhile, some of the oil treatments attained bulb yields which did not differ significantly when compared to the untreated control (Table 1). Data presented in Table 1 shows that, the lowest yield in both sites was obtained from the untreated control treatment $(3.3,3.7 \mathrm{~T} / \mathrm{Fed})$. That was not significantly different from the cotton oil $1.5 \%$ treatment in both sites $(4.4,3.7)$. The highest yield was obtained by Karate treatment in both sites (8.5, 9.0 $\mathrm{T} / \mathrm{Fed}$, respectively).The high concentration of some of the tested oils though had a positive biological efficacy in reducing the thrips population yet, this was not reflected on yield. The sesame oil at the highest dose gave the second best result after Karate treatment for both sites (7.9, 8.8 T/Fed, respectively) during 2006/2007 season. Followed by cotton oil 5\% (7.4, 7.2 T/Fed.). groundnut oil 5\% (7.1, $7.1 \mathrm{~T} /$ Fed.), groundnut oil 2.5\% (6.7, $6.7 \mathrm{~T} /$ fed.), sesame oil $2.5 \%$ (6.5, 7.1 T/Fed.), groundnut oil 1.5\% (6.6, $6.7 \mathrm{~T} /$ Fed.), cotton oil 2.5\%(6.8, 6.5T/Fed.), sesame oil 1.5\% (5.7,5.3 T/Fed.), sunflower oil 5\% (5.0, 4.6T/Fed.), sunflower oil 2.5\% (4.6, 5.9 T/Fed.) and sunflower oil 1.5\% (4.1, $4.9 \mathrm{~T} / \mathrm{Fed}$.), respectively.

The same pattern was observed in site one in season 2007/2008, (Table 2).No significant differences between treatments were found in site two during 2007/2008 season. Generally, higher yields were recorded in season $2007 / 2008$ at both sites with clear superiority to Karate treatment across the two seasons and at the two sites. The significantly highest yield was obtained from the Karate treatment (7.5, 7.5 T/Fed.). The lowest yield in both sites were obtained from the untreated control treatment (4.7, 6.0 T/Fed.). But sesame oil $5 \%$ resulted in significant higher yield in both sites $(8.3,7.7 \mathrm{~T} /$ Fed.), followed by groundnut oil 5\%treatment (8.1,7.5 T/Fed.), cotton oil 5\% (7.3,7.3 T/Fed.), sunflower oil 5\% (7.0, 7.9 T/Fed.) sesame oil 2.5\%treatment (7.3,7.2 T/Fed.), groundnut oil 2.5\% (7.3, 7.4 T/Fed.), sunflower oil 2.5\% (7.7,6.9 T/Fed.), groundnut oil 1.5\% (6.0,8.4 T/Fed.), cotton oil 2.5\% (6.7,7.0 T/Fed.), cotton oil 1.5\% (6.1,7.5 T/Fed.), sesame oil 1.5\% (6.1,6,2 T/Fed.), and sunflower oil 1.5\% (5.4,5.2 T/Fed.).

\section{Economic evaluation}

Researcher managed experiment on thrips control in onion were conducted at the Gezira research station Farm, during season 2007-2008 to test the efficiency of different concentrations of some oils and the standard Karate to evaluate their effects on the productivity of onion. The tested oils included cotton, sesame and groundnut at two concentration levels (2.5\% and 5\%). These six treatments were compared with the standard one (Karate). Data collected from on-station experiment was economically evaluated to arrive at the most economic optimum concentration level of oil and suitable oil form through assessing the profitability of these forms and levels. The combined analysis was conducted to test the statistical differences in onion yield between the different treatments. Furthermore, partial budget marginal and dominance analysis were used to a chieve the stated objectives of the study, to show the relative profitability of these oils and to rank the recommended form and level of oil according to its economic viability. The value of onion yield that has resulted from different concentration level of oils were compared with the cost of oil in question. Only costs of oil were considered in the partial budget for being the only variable cost of production that affects the productivity of onion. The marginal rate of return (MRR) which reflects the relationship between the variable cost of oils form and concentration level and the net benefits between these oils is equal in the marginal net benefit divided by the related marginal cost of each treatment.

Results of the statistical analysis showed that high levels of sesame (5\%) and groundnut oils ranked top followed by Karate and cotton (5\%) and then sesame $(2.5 \%)$ and cotton $(2.5 \%)$. Some of these treatments may have high net benefit but at a high cost. For this reason, further, dominance and marginal analysis each conducted to rank the most cost effective form and level of oil (Table 3). 


\begin{tabular}{|l|c|c|c|c|c|c|c|}
\hline \multicolumn{1}{|c|}{ Treatments } & $\begin{array}{c}\text { Yield } \\
\text { (t/fed) }\end{array}$ & TR (SDG/fed) & $\begin{array}{c}\text { Oil Quantity } \\
\text { (litre/ fed) }\end{array}$ & $\begin{array}{c}\text { Oil cost } \\
\text { (SDG/litre }\end{array}$ & $\begin{array}{c}\text { Total cost } \\
\text { (SDG/litre }\end{array}$ & $\begin{array}{c}\text { Net } \\
\text { Revenue }\end{array}$ & Dominance \\
\hline Cotton 2.5\% & 6.7 & 4690 & 3.8 & 8.000 & 30.4 & 4660 & \\
\hline Karate & 7.5 & 5250 & 0.25 & 128 & 32 & 5218 & \\
\hline Sesame 2.5\% & 6.8 & 4760 & 3.8 & 10 & 38 & 4722 & $\mathrm{D}$ \\
\hline G/N 5\% & 8.1 & 5670 & 7.5 & 6 & 45 & 5625 & \\
\hline Cotton 5\% & 7.3 & 5110 & 7.5 & 8 & 60 & 5050 & $\mathrm{D}$ \\
\hline Sesame 5\% & 8.3 & 5810 & 7.5 & 10 & 75 & 5735 & \\
\hline
\end{tabular}

Table 3: Dominance analysis of the effect of some oils and Karate on onion yield under Gezira conditions.

Onion price equals 700 SDG/ Tone, $\mathrm{D}=$ Dominance

In this respect, the dominance and marginal analysis showed that sesame (5\%), groundnut (5\%), and Karate, respectively, were the most economic optimum form and levels of oils for controlling thrips under the Gezira condition (table 4). It is obvious that cotton $(5 \%)$ and sesame $(2.5 \%)$ have net return higher than that of cot- ton $(2.5 \%)$ but at higher cost. For this reason, they are dominated by sesame and groundnut at $5 \%$. This means that yield advantage does not compensate for the increase in the cost of oil applied and then excluded from further analysis for not being economically viable.

\begin{tabular}{|l|c|c|c|c|c|c|}
\hline \multicolumn{1}{|c|}{ Treatments } & Yield (t/fed) & Net Revenue & Total cost (SDG/fed) & MR & MC & MRR \\
\hline Cotton 2.5\% & 6.7 & 4660 & 30.4 & 0 & 0 & 0 \\
\hline Karate & 7.5 & 5218 & 32 & 558 & 1.6 & 349 \\
\hline G/N 5\% & 8.1 & 5625 & 45 & 407 & 13 & 31 \\
\hline Sesame 5\% & 8.3 & 5735 & 75 & 110 & 30 & 4 \\
\hline
\end{tabular}

Table 4: Marginal analysis on the effect of some oils and Karate on onion production under Gezira conditions.

MR: Marginal Revenue

MC: Marginal Cost MRR: Marginal Rate of Return.

\section{Conclusion}

The statistical and economic analysis showed that sesame (5\%), groundnut (5\%) and Karate are the most economic optimum forms and levels of oils and insecticide for controlling thirps under the Gezira conditions, respectively.

This study laid a base line information of using such oils and other products of plant origin to control insect pests on other vegetable and edible crops.

\section{Bibliography}

1. Hala AH. Screening onion breeding lines for resistance to onion thrips. M.Sc. Thesis. University of Gezira (2001): 1-3.

2. ELhassan HS. Vegetable Production in the Sudan. In: Integrated Vegetable Crop Management in the Sudan: Aparticipatory Approach (Dabrowski, Z. T, ed.). ICIPE Science Press. Kenya (1994): 16-17.
3. FAO. Production Year Book 49 (1995): 139.

4. Omara SK. Crop production. Personal communication (1999).

5. Nonnecke BL. Vegetable Production. Van Nostrand Reinhold. New York. (1989): 295-301.

6. Bakheit IB. “Onion pests". In: Vegetable IPM, IPM project, Agri. Rec. Corp., Wad Medani, Sudan, publication No 23 (1993): 197-200.

7. Jacobson M. Insecticides from plants, A review of the literature, 1941- 1953, Agriculture Handbook, United States Department of Agriculture (1953).

8. Yassin AM., et al. "Leaf curl epidemic, a threat to tomato production in the Sudan". Annales de l'Institut Pasteur / Virologie 133 (1982): 175-181. 
9. Elamin EM. Use of oils in the whitefly control on tomatoes. Report presented during 2nd Annual and Review Meeting, FAO/ARC IPM Project, Agricultural Research Corporation, Wad Medani (1995).

10. Cranshaw WS. Onion Thrips. Colorado State University Cooperative Extension (1995-1999) (1999).

11. Kannan HO and Mohamed MB. "The impact of irrigation frequency on population density of thrips, Thrips tabaci (Thripidae, Thysanoptera) and onion yield in ELRahad, Sudan". Annals of Applied Biology 138 (2004): 129-132.

\section{Volume 3 Issue 8 August 2019}

(c) All rights are reserved by Ammar MS Abdalla., et al. 